\title{
PENGGUNAAN MODEL PEMBELAJARAN DISCOVERY LEARNING MELALUI MEDIA WORD SQUARE UNTUK MENINGKATKAN KEAKTIFAN DAN KETUNTASAN BELAJAR SISWA PADA POKOK BAHASAN LARUTAN ELETROLIT DAN NON ELEKTROLIT DAN KOLOID DI KELAS X KIMIA ANALIS SMKN 2 PEKANBARU
}

\author{
Lidiana Fitri*, Nofianti \\ SMKN 2 Pekanbaru \\ Email : nofianti@grad.unri.ac.id
}

\begin{abstract}
This research study about application of discovery learning model through word square media to increase activity and student mastery learning. This research goal to know whether discovery learning model through word square media can increase activity and student mastery learning and whether this model were pleased by student. This research is class action research consisted of 2 cycle, where first cycle is electrolyte and non-electrolyte solutions chapter and second cycle is colloid. This research done in SMKN 2 Pekanbaru at X Kimia Analis class in year 2016/2017. In this research, data collected with teacher and student observation sheet, LKS and evaluation value, block test value and student perception enquette in lerning as supporter data. As for result obtained for the student activity, clasical student mastery learning according to national and school standard in first cycle average are 53,40\%, 96,97\% and 93,94\% and also for second cycle are $65,36 \%, 100 \%$ and $93,94 \%$. Student perception to study discovery learning through word square media applied get positive respon, this matter can see from student percentage amount chosening very agree and agree for the first cycle and second cycle enquette answer successively are $91,73 \%$ and $93,47 \%$.
\end{abstract}

Key Words : Learning Model, Discovery Learning, Word Square, Electrolyte and Non-Electrolyte, Colloid

\begin{abstract}
Abstrak
Penelitian ini membahas tentang penggunaan model pembelajaran discovery learning melalui media word square untuk meningkatkan keaktifan dan ketuntasan belajar siswa. Adapun tujuan penelitian ini untuk mengetahui apakah model pembelajaran discovery learning melalui media word square dapat meningkatkan keaktifan dan ketuntasan belajar siswa dan apakah model pembelajaran ini disenangi oleh siswa. Penelitian ini merupakan penelitian tindakan kelas yang terdiri dari 2 siklus, dimana siklus I merupakan pokok bahasan larutan elektrolit dan non elektrolit dan siklus II adalah pokok bahasan koloid. Adapun penelitian ini dilakukan di SMKN 2 Pekanbaru pada kelas X Kimia Analis tahun ajaran 2016/2017. Data penelitian yang dikumpulkan dalam penelitian ini berupa lembar observasi siswa dan guru, nilai LKS dan evaluasi, nilai ujian blok dan angket persepsi siswa terhadap pembelajaran yang merupakan
\end{abstract}


data pendukung. Adapun hasil yang diperoleh untuk keaktifan siswa, ketuntasan belajar siswa klasikal menurut standar sekolah dan nasional secara berturut-turut untuk siklus I rata-ratanya adalah 53, 40\%, 96,97\% dan 93,94\% serta untuk siklus II adalah 65,36\%, 100\% dan 93,94\%. Persepsi siswa terhadap model pembelajaran discovery learning melalui media word square yang diterapkan mendapat respon positif, hal ini dapat dilihat dari jumlah persentase siswa yang memilih sangat setuju dan setuju untuk jawaban angket siklus I dan II berturutturut adalah 91,73\% dan 93,47\%.

Kata Kunci: Model Pembelajaran, Discovery Learning, Word Square, Elektrolit dan Non Elektrolit, Koloid

\section{PENDAHULUAN}

Mata pelajaran kimia adalah salah satu mata pelajaran dalam rumpun sains yang menuntut siswa atau peserta didik terampil dalam menerapkan konsep dan prinsip sains yang diperoleh sehingga menghasilkan siswa atau peserta didik yang berkualitas dibidang sains itu sendiri. Pembelajaran kimia disekolah tentunya kurang tepat jika hanya memperhatikan produk tanpa memperdulikan proses yang berlangsung dalam setiap pembelajaran. Hal ini terjadi karena minimnya model pembelajaran yang diterapkan di SMK, kebanyakan pembelajaran masih didominasi oleh guru, sehingga membuat aspek kognitif, psikomotor dan afektif siswa kurang mengalami perkembangan. (Mudalara, Iputu (2012)

Kriteria ketuntasan minimal untuk kelas X Kimia SMKN 2 Pekanbaru adalah $78(\mathrm{KKM} \leq 78)$, dari nilai ulangan harian siswa di tahun sebelumnya menunjukkan bahwa ketuntasan belajar siswa untuk pokok bahasan yang bersifat hitungan dan sedikit teori masih banyak dibawah KKM, hal ini dilihat dari hasil belajar pada mata pelajaran tersebut nilai rata-ratanya $\leq 78$. Siswa kelas X kimia SMKN 2 Pekanbaru tahun ajaran 2016-2017 banyak siswa yang mendapatkan nilai di bawah KKM yaitu $\leq 78$. Selain itu diketahui juga bahwa keaktifan siswa dalam proses pembelajaran masih sangat kurang.

Demi mengatasi masalah diatas, perlu diterapkan suatu model pembelajaran yang dapat mengaktifkan siswa dan penyajian media dengan lebih menarik, pembelajaran yang dimaksud adalah pembelajaran yang tidak hanya mampu dengan materi saja tetapi mampu menekankan kepada proses keterlibatan 
siswa secara penuh untuk dapat mengkaitkan dengan situasi kehidupan nyata sehingga mendorong siswa untuk dapat menerapkannya dalam kehidupan mereka.

Salah satu model pembelajaran yang dapat diterapkan untuk mempelajari materi elektrolit dan nonelektrolit dan koloid adalah dengan menggunakan model pembelajaran discovery learning melalui media word square yang merupakan konsep belajar yang dapat membantu guru mengkaitkan antara materi yang diajarkan dengan situasi dunia nyata siswa dan mendorong siswa membuat hubungan antara pengetahuan yang dimilikinya dengan penerapannya dalam kehidupan mereka (Rusman, 2012). Siswa diarahkan untuk mempelajari topik tertentu yang akan disampaikan lalu menemukan istilah dalam word square yang relevan dengan topik yang telah dipelajari, selanjutnya siswa memberikan penjelasan tentang kata yang ditemukan dan menggali informasi/pengetahuan siswa. Penjelasan siswa divariasikan dengan pertanyaan-pertanyaan yang ditujukan kepada seluruh siswa.

Pembelajaran discovery learning adalah suatu model untuk mengembangkan cara belajar siswa aktif dengan menemukan dan menyelidiki sendiri, maka hasil yang diperoleh akan setia dan tahan lama dalam ingatan, tidak akan mudah dilupakan siswa. Anak juga bisa berfikir analisis dan mencoba memecahkan sendiri problem yang dihadapi dengan belajar menemukan. Kebiasaan ini akan ditransfer dalam kehidupan bermasyarakat. Adapun sintaks dari model discovery learning adalah stimulasi/pemberian ransangan, pernyataan/identifikasi masalah, pengumpulan data, pengolahan data, pembuktian dan menarik kesimpulan.

Word square adalah sejumlah kata yang tersusun satu dibawah yang lain dalam bentuk bujur sangkar dan dibaca secara mendatar dan menurun. Permainan word square merupakan permainan yang memadukan kemampuan menjawab pertanyaan dengan ketelitian dan kejelian dalam mencocokkan jawaban pada kotak-kotak jawaban.

Berdasarkan uraian tersebut, maka penulis tertarik untuk melakukan penelitian dengan judul : "Penggunaan Model Pembelajaran Discovery Learning Melalui Media Word Square untuk Meningkatkan Keaktifan dan Ketuntasan 
Belajar Siswa Pada Pokok Bahasan Larutan Eletrolit dan Non Elektrolit dan Koloid di Kelas X Kimia Analis SMKN 2 Pekanbaru”

\section{METODE PENELITIAN}

Penelitian ini merupakan penelitian tindakan kelas (Classroom Action Research) yang merupakan suatu daur atau siklus yang termasuk ke dalam penelitian tindakan (Action Research) (Wardani dkk, 2002). Adapun siklus pertama pada penelitian ini adalah Larutan Elektrolit dan non elektrolit, siklus kedua adalah koloid. Diakhir siklus akan diadakan refleksi yang berguna untuk perbaikan pada siklus berikutnya.

Jumlah keseluruhan kelas X Kimia terdiri dari 2 kelas, dalam penelitian diambil kelas X Kimia Analis menjadi subjek penelitian. Kelas X Kimia Analis terdiri dari 33 orang siswa. Teknik Analisis data dalam penelitian yaitu hasil tes yang dilakukan pada akhir pembelajaran. Ketuntasan belajar kimia siswa dianalisis dengan melihat ketuntasan belajar siswa secara individu yaitu standar minimal daya serap siswa sebanyak $75 \%$ dan secara klasikal $100 \%$.

Persentase ketuntasan belajar siswa pada setiap indikator dari seluruh individu dihitung dengan menggunakan rumus :

$$
\mathrm{PKI}=\frac{S P}{S M} \times 100 \%
$$

$$
\begin{aligned}
\text { Keterangan : } & \text { PKI } \\
\text { SP } & =\text { Persentase ketuntasan individu } \\
\text { SM } & =\text { Skor mang diperoleh siswa } \\
&
\end{aligned}
$$

Persentase ketuntasan hasil belajar siswa pada setiap indikator secara klasikal dapat dihitung dengan rumus :

$$
\mathrm{PKK}=\frac{J T}{J S} \times 100 \%
$$

Keterangan: PKK = Persentase ketuntasan klasikal

JT = Jumlah siswa yang tuntas

JS = Jumlah seluruh siswa 
Persentase ketuntasan indikator individu per 1 indikator dapat dihitung dengan rumus :

$$
=\frac{\text { Skor yang dicapaidalamsatu indikator X }}{\text { Skor maksimum satu indikator }} 100 \%
$$

Persentase ketuntasan indikator klasikal dapat dihitung dengan rumus :

$$
=\frac{\text { JumlahSiswa yang tuntas indikator X } 100 \%}{\text { Jumlah siswa }}
$$

(Depdikbud, 1995).

Selain ketuntasan belajar siswa dapat juga dianalisis aktivitas siswa dan guru pada setiap pembelajaran berdasarkan lembar observasi siswa dan guru yang diamati oleh observer. Aktivitas siswa dapat diketahui dengan menggunakan rumus sebagai berikut:

$$
\mathrm{P}=\prod^{F} \times 100 \%
$$

Dimana: $\mathrm{P}=$ Angka persentase

$\mathrm{F}=$ Frekuensi aktivitas siswa

$\mathrm{N}=$ Banyak siswa

Aktivitas siswa tersebut dapat diketahui dengan memberikan nilai observasi tersebut sesuai dengan kategori penilaian sebagai berikut: Tabel 1 . Kategori Penilaian Aktivitas Siswa

\begin{tabular}{cc}
\hline \% Interval & Kategori \\
\hline $75-100$ & Baik sekali \\
$65-74$ & Baik \\
$55-64$ & Cukup \\
$\leq 54$ & Kurang baik \\
\hline
\end{tabular}

(Sudijono, 2004)

\section{HASIL DAN PEMBAHASAN}

Penelitian ini merupakan penelitian tindakan kelas. Penelitian ini terdiri dari 2 siklus, siklus pertama merupakan pokok bahasan larutan elektrolit dan non elektrolit dan siklus kedua adalah pokok bahasan koloid. Proses pembelajaran dalam penelitian ini menggunakan model pembelajaran discovery learning 
melalui media word square. Adapun aspek yang diamati dalam penelitian ini adalah keaktifan siswa, nilai LKS, nilai evaluasi, poin dalam pertandingan dan nilai ujian blok pada setiap siklus.

Berikut adalah hasil analisis data siklus I dan siklus II yang dikumpulkan peneliti selama penelitian berlangsung.

\section{Siklus I}

\section{a. Keaktifan Siswa}

Hasil analisis data aktivitas siswa untuk siklus I dapat dilihat pada Tabel 2.

Tabel 2. Aktivitas Siswa dalam Pembelajaran Siklus I

\begin{tabular}{|c|c|c|c|c|c|c|c|}
\hline \multirow{2}{*}{ No } & \multirow{2}{*}{$\begin{array}{c}\text { Aspek yang } \\
\text { diamati }\end{array}$} & \multicolumn{4}{|c|}{ Pertemuan } & \multirow{2}{*}{ Rerata } & \multirow{2}{*}{ Kategori } \\
\hline & & I & II & III & IV & & \\
\hline 1 & Bertanya & $27,78 \%$ & $33,33 \%$ & $44,44 \%$ & $38,89 \%$ & $36,11 \%$ & Kurang \\
\hline 2 & $\begin{array}{l}\text { Menjawab } \\
\text { pertanyaan }\end{array}$ & $27,78 \%$ & $27,78 \%$ & $55,56 \%$ & $50 \%$ & $40,28 \%$ & Kurang \\
\hline 3 & $\begin{array}{l}\text { Mengerjakan } \\
\text { LKS }\end{array}$ & $100 \%$ & $100 \%$ & $100 \%$ & $100 \%$ & $100 \%$ & $\begin{array}{l}\text { Baik } \\
\text { sekali }\end{array}$ \\
\hline 4 & $\begin{array}{l}\text { Berdiskusi } \\
\text { Membantu }\end{array}$ & $42,42 \%$ & $31,51 \%$ & $42,42 \%$ & $54,54 \%$ & $42,72 \%$ & Kurang \\
\hline 5 & $\begin{array}{l}\text { Teman dalam } \\
\text { kelompok }\end{array}$ & $25 \%$ & $27,86 \%$ & $35,72 \%$ & $41,07 \%$ & $32,41 \%$ & Kurang \\
\hline 6 & $\begin{array}{l}\text { Melakukan } \\
\text { praktikum }\end{array}$ & - & $63,64 \%$ & - & - & $63,64 \%$ & Cukup \\
\hline 7 & $\begin{array}{l}\text { Menyimpulkan } \\
\text { pelajaran }\end{array}$ & $33,33 \%$ & $100 \%$ & $66,67 \%$ & $66,67 \%$ & $66,67 \%$ & Baik \\
\hline & Rerata & $42,72 \%$ & $54,87 \%$ & $57,47 \%$ & $58,53 \%$ & $53,40 \%$ & \\
\hline & Kategori & Kurang & Kurang & cukup & cukup & Kurang & \\
\hline
\end{tabular}

Berdasarkan Tabel di atas dapat dilihat bahwa keaktifan siswa masih kurang dari aspek bertanya, menjawab, berdiskusi dan membantu teman dalam kelompok. Namun untuk aspek mengerjakan LKS, melakukan praktikum dan menyimpulkan pelajaran secara berturut-turut telah termasuk dalam kategori baik sekali, cukup dan baik. 


\section{b. Nilai LKS (Lembar Kerja Siswa) dan Nilai Evaluasi}

Hasil analisis data nilai LKS dan nilai evaluasi siswa untuk siklus I dapat dilihat pada Tabel 3. Berdasarkan Tabel 3 diketahui bahwa rata-rata nilai LKS siswa setiap pada pertemuan 1 hingga pertemuan 4 semakin meningkat, sedangkan rata-rata nilai evaluasi siswa menurun pada pertemuan ke-3.

Tabel 3. Nilai LKS dan Evaluasi dalam Pembelajaran Siklus I

\begin{tabular}{ccc}
\hline Pertemuan & Rata-rata Nilai LKS $(\%)$ & Rata-rata Nilai Evaluasi (\%) \\
\hline I & $91,94 \%$ & $76,33 \%$ \\
II & $92,27 \%$ & $87,42 \%$ \\
II & $94,37 \%$ & $69,85 \%$ \\
IV & $99,13 \%$ & $81,06 \%$ \\
Rata-rata & $94,43 \%$ & $78,67 \%$ \\
\hline
\end{tabular}

\section{c. Ketuntasan Belajar Siswa}

1) Ketuntasan belajar siswa individu

Ketuntasan belajar siswa menurut standar ketuntasan nasional dan standar ketuntasan sekolah dengan nilai $\geq 78$, adapun data hasil ketuntasan belajar siswa pada siklus I disajikan pada Tabel 4 dibawah ini.

Tabel 4. Ketuntasan Belajar Siswa Individu Siklus I

\begin{tabular}{cccccc}
\hline \multirow{2}{*}{ No } & \multirow{2}{*}{ Skor yang diperoleh } & \multirow{2}{*}{ \% PKI } & \multirow{2}{*}{ Jumlah Siswa } & \multicolumn{2}{c}{ Keterangan } \\
\cline { 5 - 6 } & & 100 & 1 & STDS & STDN \\
\hline 1 & 100 & 96 & 4 & $\mathrm{~T}$ & $\mathrm{~T}$ \\
2 & 96 & 92 & 5 & $\mathrm{~T}$ & $\mathrm{~T}$ \\
3 & 92 & 88 & 13 & $\mathrm{~T}$ & $\mathrm{~T}$ \\
4 & 88 & 84 & 4 & $\mathrm{~T}$ & $\mathrm{~T}$ \\
5 & 84 & 80 & 4 & $\mathrm{~T}$ & $\mathrm{~T}$ \\
6 & 80 & 72 & 1 & $\mathrm{TT}$ & $\mathrm{TT}$ \\
7 & 72 & 52 & 1 & $\mathrm{TT}$ & $\mathrm{TT}$ \\
8 & 52 & & 31 & 31 \\
\hline
\end{tabular}

\begin{aligned} \hline Keterangan : STDS & $=$ Standar ketuntasan sekolah \\ STDN & $=$ Standar ketuntasan nasional \\ T & $=$ Tuntas \\ TT & $=$ Tidak tuntas \end{aligned}


Berdasarkan Tabel 4 dapat diketahui bahwa terdapat 2 orang siswa yang tidak tuntas menurut STDS dan 2 orang siswa yang tidak tuntas menurut STDN.

2) Ketuntasan belajar siswa klasikal

Berikut merupakan Tabel ketuntasan belajar siswa klasikal.

Tabel 5. Ketuntasan Belajar Siswa Klasikal

\begin{tabular}{rrrccc}
\hline \multirow{2}{*}{ No } & \multirow{2}{*}{ Kriteria } & \multicolumn{4}{c}{ Jumlah Siswa } \\
\cline { 3 - 6 } & & STDS & $(\%)$ & STDN & $(\%)$ \\
\hline 1 & Tuntas & 31 & 93,94 & 31 & 93,94 \\
2 & Tidak tuntas & 2 & 6,06 & 2 & 6,06 \\
& Jumlah & 33 & 100 & 33 & 100 \\
\hline Keterangan : STDS & $=$ Standar ketuntasan sekolah \\
STDN & $=$ Standar ketuntasan nasional & \\
T & $=$ Tuntas & & \\
TT & $=$ Tidak tuntas
\end{tabular}

Berdasarkan Tabel 5 dapat dilihat bahwa jumlah persentase siswa yang tuntas menurut STDS dan STDN adalah 93,94\%.

\section{d. Refleksi Siklus I}

Refleksi Siklus I dilakukan untuk evaluasi hasil tindakan siklus I. Refleksi siklus I ini mengGambarkan hasil tindakan secara keseluruhan. Gambaran tersebut dapat dilihat pada Gambar 1.

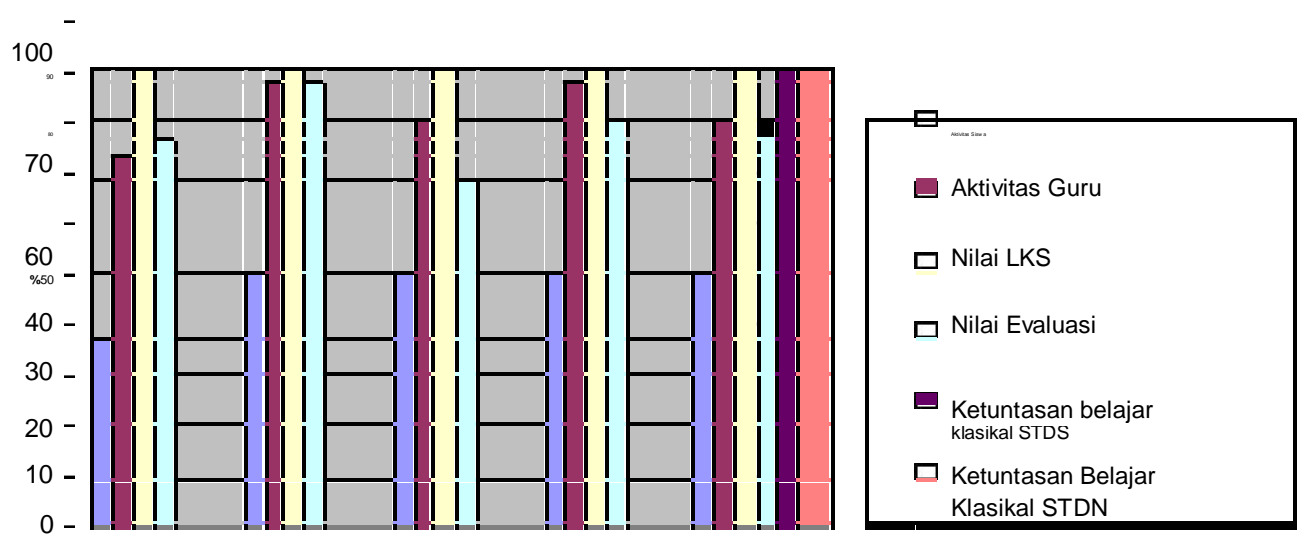

Gambar 1. Grafik Refleksi Hasil Tindakan Siklus I 
Secara keseluruhan tindakan siklus I dapat dilihat dari Gambar diatas. Keaktifan siswa untuk aspek mengerjakan LKS, melakukan praktikum dan menyimpulkan pelajaran secara berturut-turut telah termasuk dalam kategori baik sekali, cukup dan baik, namun keaktifan siswa untuk aspek bertanya, menjawab, berdiskusi dan membantu teman dalam kelompok masih kurang. Dari grafik bagian siklus I dilihat bahwa persentase aspek keaktifan siswa secara keselurhan pada siklus I sebesar 53,40\% yaitu masih tergolong kurang. Oleh karena itu untuk meningkatkan keaktifan siswa maka guru berusaha mengadakan perbaikan pada siklus II dengan penambahan perlakuan pada siklus II. Penambahan tersebut adalah dengan pemberian contoh soal lebih banyak dan bervariasi, perubahan dari segi cara menjawab soal dimana siswa harus menuliskan cara penyelesaian soal teori, memberikan kesempatan lebih luas lagi kepada siswa untuk bertanya.

\section{Siklus II}

\section{a. Aktivitas Siswa}

Hasil analisis data aktivitas siswa untuk siklus II dapat dilihat pada Tabel 6.

Tabel 6. Aktivitas Siswa dalam Pembelajaran Siklus II

\begin{tabular}{clccccc}
\hline \multirow{2}{*}{ No } & Aspek yang diamati & \multicolumn{3}{c}{ Pertemuan } & \multirow{2}{*}{ Rerata } & \multirow{2}{*}{ Kategori } \\
\cline { 2 - 5 } & & I & II & III & & \\
\hline 1 & Bertanya & $53,33 \%$ & $86,67 \%$ & $80,00 \%$ & $73,33 \%$ & Baik \\
2 & Menjawab pertanyaan & $53,33 \%$ & $66,67 \%$ & $60 \%$ & $60 \%$ & Cukup \\
3 & Mengerjakan LKS & $100 \%$ & $100 \%$ & $100 \%$ & $100 \%$ & Baik \\
& & & & & \\
4 & Bekali \\
& Berdiskusi & $42,42 \%$ & $44,44 \%$ & $54,55 \%$ & $47,14 \%$ & Kurang \\
5 & Membantu Teman dalam & $42,86 \%$ & $41,67 \%$ & $40,34 \%$ & 41,62 & Kurang \\
& kelompok & & & & & Baik \\
6 & Melakukan praktikum & - & - & $78,79 \%$ & $78,79 \%$ & sekali \\
7 & Menyimpulkan pelajaran & $66,67 \%$ & $66,67 \%$ & $66,67 \%$ & $66,67 \%$ & Baik \\
& $\quad$ Rerata & $59,77 \%$ & $67,69 \%$ & $68,62 \%$ & $65,36 \%$ & \\
\cline { 5 - 6 } & Kategori & Cukup & Baik & Baik & Baik & \\
\hline
\end{tabular}

Berdasarkan Tabel 6 diatas dapat diketahui bahwa aktivitas siswa dari segi berdiskusi dan membantu teman dalam kelompok masih dalam 
interval kurang, namun persentase aktivitas ini telah meningkat bila dibandingkan degan siklus I. Aktivitas bertanya, menjawab pertanyaan dan melakukan praktikum untuk siklus II ini telah menunjukkan perubahan dari siklus I yang semula aktivitas bertanya masih tergolong kurang pada siklus II sudah tergolong baik, semula aktivitas menjawab pertanyaan tergolong kurang pada siklus II sudah tergolong cukup dan melakukan praktikum yang semula baik ternyata pada siklus II sudah tergolong baik sekali.

\section{b. Refleksi}

Refleksi Siklus II dilakukan untuk evaluasi hasil tindakan siklus II. Gambaran hasil tindakan siklus II secara keseluruhan dapat dilihat pada Gambar 2. Berdasarkan grafik pada Gambar 2 bagian siklus II dapat diketahui hasil tindakan siklus II secara keseluruhan. Dari grafik dapat dilihat bahwa aktivitas siswa siklus II telah mencapai 65,36\% artinya telah tergolong dalam interval baik. Secara keseluruhan tindakan siklus II sudah memuaskan, hanya saja dari aktivitas siswa dari aspek berdiskusi dan membantu teman dalam kelompok masih tergolong kurang, tetapi persentasenya telah meningkat bila dibandingkan siklus I. Karena penelitian ini hanya dilakukan dalam 2 siklus maka perbaikan yang dilakukan juga terbatas pada siklus II, jika penelitian ini dilanjutkan maka pada siklus berikutnya guru harus lebih meningkatkan aktivitas siswa dari segi berdiskusi dan membantu teman dalam kelompok, serta mencari cara agar siswa dengan mudah dalam mengerjakan soal hitungan. 


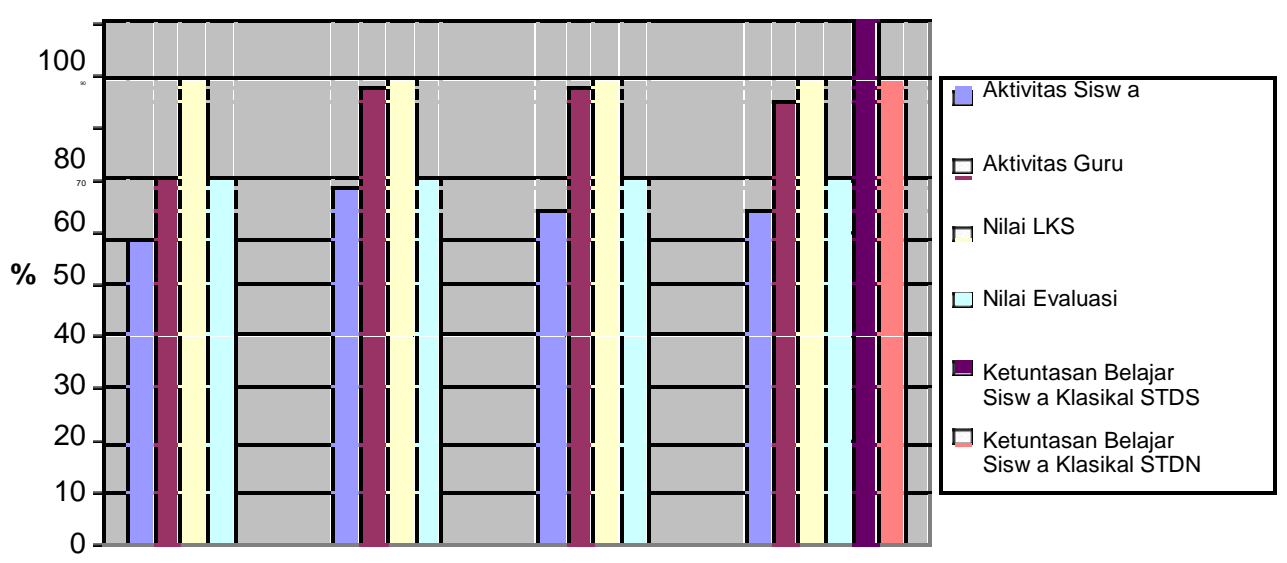

Gambar 2. Grafik Refleksi Hasil Tindakan Siklus II

Ketuntasan indikator ada dua jenis yaitu ketuntasan indikator individu dan ketuntasan indikator klasikal. Siklus II menunjukkan ketuntasan indikator individu untuk standar sekolah telah mencapai $100 \%$ hal ini berarti telah terjadi peningkatan bila dibandingkan dengan siklus I. Begitu juga dengan ketuntasan indikator klasikal untuk standar nasional meningkat dari siklus I sebesar 3,03\%.

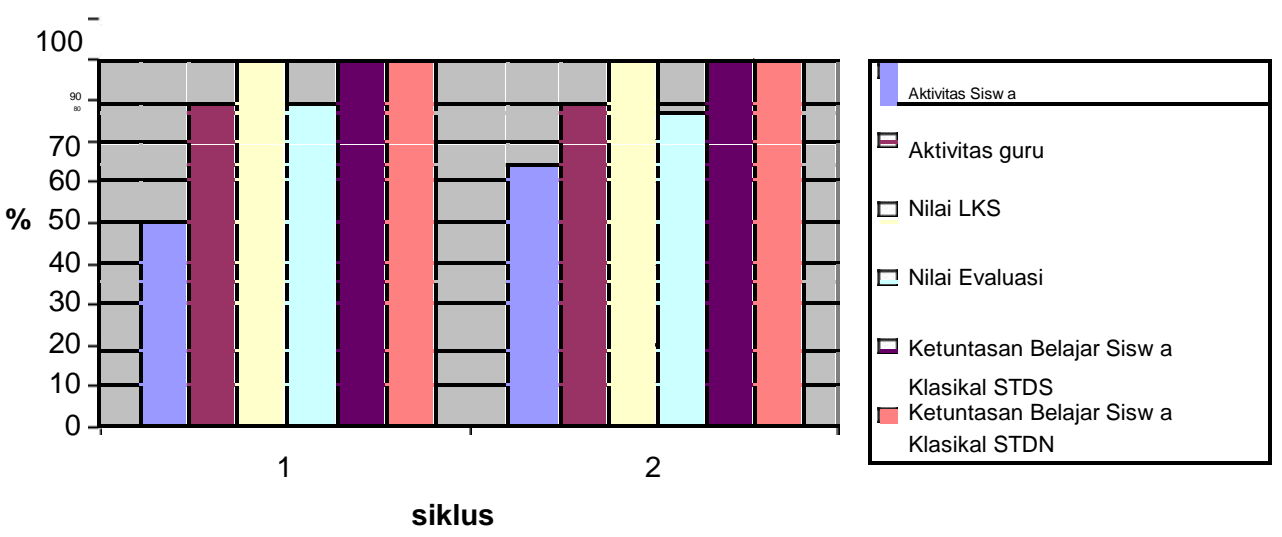

Gambar 3. Grafik Perbandingan Kegiatan Pada Siklus I Dan Siklus II

Secara keseluruhan kegiatan pembelajaran pada siklus I dan II, disajikan Gambar 3. Berdasarkan grafik di atas dapat dilihat bahwa aspek yang mengalami peningkatan dari siklus I ke siklus II yaitu aktivitas siswa, aktivitas guru, dan ketuntasan belajar siswa. Keaktifan siswa pada siklus II 
mengalami peningkatan sebesar 11,96\%, hal ini menunjukkan bahwa penambahan perlakuan yang dilakukan pada siklus II menunjukkan hasil yang memuaskan. Selain itu, peningkatan aktivitas siswa dari siklus I ke siklus II membuktikan bahwa penerapan model pembelajaran discovery learning melalui media word square dapat meningkatkan aktivitas siswa. Peningkatan aktivitas siswa ini akan berdampak pada ketuntasan belajar siswa. Hal ini terlihat dari aktivitas siswa yang dominan pada saat berlangsungnya proses belajar mengajar adalah siswa mendengarkan penegasan dari guru serta kerjasama dan interaksi sesama teman sekelompok semakin kuat. Dari hasil analisis data terhadap hasil belajar dan aktivitas siswa diperoleh Gambaran bahwa pembelajaran dengan model discovery learning melalui media word square sudah berlangsung seperti yang diharapkan.

Guru berusaha meningkatkan keaktifan siswa dengan cara memberikan kesempatan lebih luas lagi kepada siswa untuk bertanya, memberikan kesempatan kepada siswa untuk menjawab pertanyaan yang ditanyakan oleh temannya kepada guru, memberikan penguatan setiap kali siswa memberikan respon yang diinginkan, mengarahkan siswa dalam menjawab soal yang diberikan, dan menjelaskan kepada siswa bahwa nilai individu ditentukan oleh kelompok adalah artinya setiap siswa harus bisa mengerjakan soal yang diberikan agar nilai kelompok mereka tinggi sehingga nilai individunya juga tinggi. Aktivitas siswa yang lainnya dapat diaktifkan dengan cara guru memberikan motivasi kepada siswa dan melakukan penyebaran dalam memberikan kesempatan bertanya dan menjawab pertanyaan. Hal ini sesuai dengan pendapat Anwar (2006) yang menyatakan bahwa siswa yang termotivasi cendrung akan mengembangkan kemampuannya mencapai keberhasilan belajar. Setelah diadakan refleksi, maka dapat dilihat pada siklus II frekuensi munculnya pertanyaan dan jawaban mengalami peningkatan begitu juga dengan jumlah siswa yang bertanya dan menjawab tidak siswa itu-itu saja melainkan sudah bervariasi. 


\section{KESIMPULAN}

Berdasarkan hasil analisis data dan pembahasan dapat disimpulkan bahwa model pembelajaran discovery learning melalui media word square pada pokok bahasan larutan elektrolit dan elektrolit dan koloid di kelas X kimia analis SMKN 2 Pekanbaru dapat meningkatkan keaktifan dan ketuntasan belajar siswa. Hal ini dapat terlihat dari terjadinya peningkatan persentase keaktifan siswa dari siklus I ke siklus II sebesar 11,96\% dan peningkatan persentase ketuntasan belajar siswa klasikal menurut standar dari siklus I ke siklus II sekolah sebesar 3,03\%.

\section{DAFTAR PUSTAKA}

Anwar, 2006, Penggunaan Peta Konsep Melalui Pembelajaran Kooperatif Tipe STAD untuk Meningkatkan Proses, Hasil Belajar dan Respon pada Konsp Ekosistem, Jurnal Penelitian Kependidikan, 16 (2), 230-243.

Depdikbud, 1995, Petunjuk Pelaksanaan Proses Belajar Mengajar SMU, Jakarta.

Mudalara, Iputu, 2012, Artikel "Pengaruh Model Pembelajaran Inkuiri Bebas Terhadap Hasil Belajar Kimia Siswa Kelas XI IPA SMA Negeri I Gianyar Ditinjau Dari Sikap Ilmiah”, Universitas Pendidikan Genesha, Bali.

Rusman, 2012, Model-Model Pembelajaran, Rajawali Pers, Jakarta.

Sudijono, A., 2004, Penilaian Hasil Proses Belajar Mengajar, Raja Grafindo Persada, Jakarta.

Wardani, I., Wihardit, K dan Nasoetion, N., 2002, Penelitian Tindakan Kelas, Pusat Penerbitan Universitas Terbuka. 